\title{
Odpowiedzialność za zobowiązania prowadzących działalność architektoniczną w formie spółek według obowiązujących przepisów
}

\author{
Wanda Misiak
}

\section{STRESZCZENIE}

Działalność architektoniczna podlega tym samym regułom, co inny rodzaj działalności gospodarczej. Sposób jej zorganizowania decyduje o sposobie odpowiedzialności za zobowiązania powstające w trakcie działalności.

Dla działalności architektonicznej najlepszą formą jest spółka partnerska. Wykonujący tę działalność mogą prowadzić ją w innych formach, a mianowicie spółek osobowych innego rodzaju niż spółka partnerska i spółkach kapitałowych.

Od formy organizacyjnej zależą zasady odpowiedzialności za zobowiązania w ramach działalności architektonicznej.

Słowa kluczowe: prawo, Kodeks spółek handlowych, spółka partnerska, spółka komandytowa, spółka z o.o., spółka europejska

Ustawa Prawo przedsiębiorców, definiując działalność gospodarczą, określa jej cechy, którymi m.in. są zarobkowy charakter i zorganizowanie. Jeżeli chodzi o pierwszą cechę, czyli zarobkowy charakter, to sprawa jest oczywista. Każdy podejmujący działalność gospodarczą stawia sobie taki cel jak uzyskanie największych profitów i to jest najczęściej priorytet podejmowanych starań.

Inaczej wygląda problem w odniesieniu do zorganizowanego charakteru działalności gospodarczej. Przedsiębiorcy podejmujący działalność gospodarcza, w tym działalność architektoniczną ${ }^{1}$, mają do wyboru różne formy organizacyjno-prawne, w ramach których ich aktywność może być realizowana. Przy wyborze odpowiedniej formy potrzebna jest znajomość jej istoty i ocena efektywności w danej sytuacji i w konkretnych warunkach, w których działalność będzie prowadzona. Niezmiernie istotnym problemem, który należy rozważyć

\footnotetext{
${ }^{1}$ Na potrzeby niniejszego artykułu za działalność architektoniczną przyjmuję przede wszystkim:

- działalność projektowanie budowlane,

- projektowanie urbanistyczne i architektoniczne,

- $\quad$ kształtowanie krajobrazu zgodnie z rozporządzeniem Rady Ministrów z dnia 24 grudnia 2007 r. Polskiej Klasyfikacji Działalności poz. 1885 z późniejszymi zmianami (Dz.U. z 2020 r., poz. 1249).
} 
przy podejmowaniu działalności, są zasady odpowiedzialności za zobowiązania, które powstają w toku podejmowanych przedsięwzięć.

Wydaje się, że optymalną formą prowadzenia działalności architektonicznej są formy, które pozwalają na zespołowe działania z uwagi na skomplikowane i trudne realizacje przyjmowanych zleceń. Statystyki wskazują że ten rodzaj działalności, jest prowadzony często indywidualnie na własny rachunek, zwłaszcza przy mniejszym rozmiarze prowadzonej działalności. Warunki do prowadzenia działalności zespołowej stwarzają spółki, chociaż i w tej formie może być prowadzona działalność przez jedną osobę.

Kryterium wyboru określonej formy dla prowadzących działalność w obszarze usług architektonicznych, jest często sposób odpowiedzialności za zobowiązania różnego rodzaju, w tym odpowiedzialność odszkodowawcza, związana z nieprawidłowościami przy wykonywaniu zleceń.

Jeżeli działalność prowadzona jest w formie spółki, to należy mieć świadomość, że regulujące ich funkcjonowanie normy prawne mają często charakter dyspozytywny, co oznacza, że można odstąpić od sposobu postępowania nakazanego w ich dyspozycji i sposób postępowania określić inaczej przez odpowiedni zapis w umowie spółki lub statucie. Dotyczy to także w wielu przypadkach odpowiedzialności za zobowiązania.

Działalność architektoniczna, prowadzona w niewielkim rozmiarze, może być realizowana w bardzo prostej formie, jaką jest spółka cywilna. Forma ta najczęściej nie jest formą docelowa, gdyż w razie rozwoju działalności, rozszerzenia jej zakresu, ulega zmianie. Odpowiedzialność za zobowiązania w tej spółce regulują przepisy Kodeksu cywilnego², jak zresztą działalność całej spółki i jest to odpowiedzialność bardzo podobna do odpowiedzialności prowadzonej indywidualnie na własny rachunek. Spółka cywilna, jako całość nie jest przedsiębiorca, a przedsiębiorcami są poszczególni wspólnicy. Odpowiadają oni za wszystkie zobowiązania całym swoim osobistym majątkiem, solidarnie z innymi wspólnikami. Spółka cywilna nie musi mieć wkładów majątkowych, a więc może być tak, że osobista odpowiedzialność własnym majątkiem jest jedyną z możliwych.

Solidarna odpowiedzialność polega na tym, że jeśli jeden wspólnik zaspokoi wierzycieli, to ma on prawo do rekompensaty ze strony pozostałych wspólników. Można również podzielić zobowiązanie na wszystkich wspólników i egzekwować w częściach od konkretnych zobowiązanych. Ten rodzaj odpowiedzialności może stać się iluzorycznym, jeśli wspólnicy do spółki majątku nie wnieśli, a sami osobistego majątku też nie posiadają. Poszkodowanymi stają się wierzyciele, którzy muszą zabiegać o swoje należności.

Kolejną formą organizacyjna, w ramach której może być prowadzona działalność architektoniczna, jest spółka jawna. Wyrosła ona ze spółki cywilnej i zawiera cały szereg do niej podobieństw. Regulowana jest jednak przez inne źródła prawa, a mianowicie Kodeks spółek handlowych ${ }^{3}$. Jest to więc spółka prawa handlowego i z tego faktu wynikają także różnice w stosunku do spółki cywilnej. Różnice te dotyczą także zasad odpowiedzialności za zobo-

${ }^{2}$ (Dz.U. z 2020 r., poz. 1740) tekst jednolity
${ }^{3}$ (Dz.U. z 2020 r., poz. 1526) tekst jednolity 
wiązania spółki. W tej spółce istotnym elementem jest odpowiedzialność subsydiarna, która działa na korzyść wspólników. Działalność subsydiarna w tym przypadku polega na tym, że za zobowiązania w pierwszej kolejności odpowiada spółka, a dopiero jeżeli majątek spółki nie wystarcza na pokrycie należności, sięga się do majątku osobistego wspólników. W takiej sytuacji wspólnicy odpowiadają w sposób pełny, całym swoim osobistym majątkiem i solidarnie. Jeżeli jednak wspólnicy wnieśli wkłady majątkowe do spółki, albo wypracowali majątek są wolni od odpowiedzialności osobistej.

W największym stopniu, formą najbardziej właściwą do prowadzenia działalności architektonicznej jest spółka partnerska. Została ona stworzona dla działalności gospodarczej wykonywanej przez wykonujących wolne zawody. Architekci należą do tej grupy osób wymienionych w art. 88 Kodeksu spółek handlowych. Istotą tej spółki jest specyficzna odpowiedzialność partnerów, czyli wspólników za zobowiązania. Bardzo dokładnie sformułował to ustawodawca w art. $95 \S 1$ K.s.h. „partner nie ponosi odpowiedzialności za zobowiązania spółki powstałe w związku z wykonywaniem przez pozostałych partnerów wolnego zawodu w spółce, jak również za zobowiązania spółki będące następstwem działań lub zaniechania osób zatrudnionych przez spółkę na podstawie umowy o pracę lub stosunku prawnego, które podlegały kierownictwu innego partnera przy realizacji usług związanych z przedmiotem działalności spółki".

Intencją ustawodawcy formującego ten przepis było to, żeby nie narazić na odpowiedzialność partnerów, którzy nie mieli swojego udziału przy wykonywaniu zlecenia obarczonego „błędem w sztuce”, co pociąga za sobą odpowiedzialność odszkodowawczą stanowiącą zobowiązanie spółki.

Działalność architektoniczna obciążona jest ryzykiem popełnienia błędu w znacznie większym stopniu niż w innych rodzajach działalności i przytoczony przepis ogranicza odpowiedzialność za popełnienie błędu tylko do grona osób przyczyniających się w stopniu bezpośrednim lub pośrednim do jego powstania. Ograniczenie to jest szczególnie przydatne w sytuacji prowadzenia działalności w dużych spółkach, zatrudniających wielu pracowników. Odpowiedzialność w spółce partnerskiej jest subsydiarna i to w sytuacji braku majątku w spółce, każdy ze wspólników ryzykowałby osobistym majątkiem za zobowiązanie odszkodowawcze, chociaż nic wspólnego z nieprawidłowościami przy wykonaniu usługi nie miał.

Podobnie jak w innych spółkach, w spółce partnerskiej istnieją zobowiązania innego rodzaju niż te związane z odpowiedzialnością odszkodowawczą. Za te inne zobowiązania odpowiadają partnerzy na zasadzie odpowiedzialności subsydiarnej razem z innymi partnerami i spółka, i dla partnerów będzie to odpowiedzialność osobista.

W spółce partnerskiej, zgodnie z postanowieniami K.s.h., można powołać organ jakim jest zarząd, jeśli umowa spółki tak stanowi. W takim przypadku członkowie zarządu mogą ponosić odpowiedzialność osobistą za zobowiązania spółki, jeśli majątek spółki nie wystarczy na pokrycie zobowiązań, a członkowie zarządu nie złożyli wniosku o postępowanie upadłościowe lub naprawcze. Zarząd jest jednak organem fakultatywnym, partnerzy mogą z niego zrezygnować i określić w umowie spółki jak nią zarządzać. 
Rozpowszechnioną formą prowadzenia działalności architektonicznej jest spółka komandytowa. Występują w niej dwa rodzaje wspólników, a mianowicie komplementariusze i komandytariusze. Podział ten wynika przede wszystkim z różnego zakresu i zasad odpowiedzialności za zobowiązania spółki oraz obowiązku wnoszenia wkładu.

Komplementariusz to taki wspólnik, który nie ma obowiązku wnoszenia wkładu majątkowego do spółki, a jego odpowiedzialność za zobowiązania spółki jest subsydiarna ze spółką i pozostałymi komplementariuszami i sprowadza się do pełnej osobistej odpowiedzialności w przypadku braku wystarczającego majątku w spółce.

Komandytariusz, to wspólnik, który ma obowiązek wnoszenia wkładu majątkowego w określonej przez umowę spółki wartości, a jego odpowiedzialność za zobowiązania jest ograniczona. Granicą odpowiedzialności komandytariusza lub komandytariuszy jest wysokość sumy komandytowej określonej przez umowę spółki. Komandytariusz, inaczej niż komplementariusz, nie ponosi pełnej, osobistej odpowiedzialności za zobowiązania spółki. Jeśli wniósł wkład majątkowy, a jest do tego zobowiązany, o wartości równej wysokości sumy komandytowej, to jest on wolny od odpowiedzialności osobistym majątkiem. W tej sytuacji istnieje możliwość kształtowania ustroju spółki w taki sposób, aby zwolnić od odpowiedzialności osobistej tych architektów, którzy przyjęli status komandytariusza i mają możliwość wniesienia do spółki majątku i tych, którzy tego majątku nie wnoszą.

Komplementariusze nie musza, ale moga, wnosić wkład majątkowy i są fachowcami od zarządzania spółką. Zgodnie z postanowieniami K.s.h., spółką zarządzać mogą tylko komplementariusze i ich właściwy dobór może mieć zasadniczy wpływ na prawidłowe funkcjonowanie spółki i to, że zobowiązania realizowane będą z majątku znajdującego się w spółce bez obciążeń jej wspólników. Leży to w interesie jednej i drugiej grupy wspólników, gdyż architekci mający status komplementariuszy nie ryzykują majątkiem osobistym a ci, którzy są komandytariuszami mogą liczyć na zwrot wkładu po zakończeniu działalności spółki.

Atrakcyjność takiej formy, jaką jest spółka komandytowa, zmniejszyła się z uwagi na nowe uregulowania, które wejdą w życie w 2021 r., a dotyczą zobowiązań finansowych. Do tej pory spółki te unikały podwójnego opodatkowania nie płacąc podatku dochodowego od osób prawnych. Spółki te będą zobowiązane do takich płatności od 1 stycznia 2021 r., a więc będą to dodatkowe obciążenia dla tych form organizacyjnych.

Prowadzący działalność architektoniczną mają również do wyboru inną jeszcze formę, czyli spółkę komandytową akcyjną, działającą w podobny sposób jak spółka komandytowa, zwłaszcza po zmianie opodatkowania spółki komandytowej. Spółka komandytowa akcyjna, to połączenie osobowej spółki komandytowej i spółki kapitałowej, jaką jest spółka akcyjna. Podobieństwo do spółki akcyjnej sprowadza się do tego, że jedna grupa wspólników, którymi są akcjonariusze ma podobną pozycję do komandytariuszy ze spółki komandytowej. Druga grupa wspólników, tak jak w spółce komandytowej, to komplementariusze o podobnych prawach i obowiązkach jak komplementariusze w spółce komandytowej.

Zasady odpowiedzialności za zobowiązania poszczególnych rodzajów wspólników wynikają z faktu, że w tej spółce występować musi substrat kapitałowy w formie kapitału aukcyjnego, który dzieli się na akcje. Akcje obowiązkowo obejmują akcjonariusze, ale mogą 
także komplementariusze, co jednak nie zmienia ich statusu. Do tej spółki musi być wniesiony kapitał wartości minimalnej 50 tys. zł.

Wspólnik będący akcjonariuszem ryzykuje tę część swojego majątku, który wniósł do spółki i przeznaczył na objęcie akcji. Nie odpowiada pozostałym majątkiem, który posiada poza spółką. Jest to więc ograniczona odpowiedzialność za zobowiązania w pełnym tego słowa znaczeniu.

Komplementariusz, to wspólnik zarządzający bieżącą działalnością spółki i mający wpływ na jej kondycję finansowa, co przyczynia się do tego czy majątek spółki wystarcza na realizację wszelkich zobowiązań.

W tej spółce, w przypadku braku wystarczającego majątku na pokrycie wszelkich należności związanych z działalnością spółki, komplementariusze ryzykują swoim osobistym majątkiem, a akcjonariusze tym co do spółki wnieśli.

Akcjonariusze do prawidłowego zarządzania przyczyniają się przez podejmowanie decyzji na zgromadzeniu wspólników w sprawach kluczowych dla spółki. Wzrost majątku spółki w tym przypadku związany jest z prawidłowym zarządzaniem nią przez komplementariuszy, wzbogacenia kapitałowego przez akcjonariuszy lub także przez komplementariuszy i w ten sposób niweluje odpowiedzialność jednej i drugiej grupy wspólników majątkiem osobistym.

Jak wynika ze statystyki dosyć częstym wyborem dla działalności architektonicznej jest forma spółki kapitałowej, a przede wszystkim spółki z ograniczoną odpowiedzialnością.

Spółki kapitałowe (sp. z o.o. i spółka akcyjna), to odrębne od wspólników przedsiębiorstwa z pełną osobowością prawną. Oznacza to, że spółka na własne konto nabywa prawa i zaciąga zobowiązania, i za te zobowiązania odpowiada całym swoim majątkiem. $\mathrm{Z}$ tego względu spółka z o.o. jest uznana za osobną formę prowadzenia działalności gospodarczej, bo eliminuje odpowiedzialność za zobowiązania.

Wykonujący działalność odpowiadają tylko tym, co do spółki wnieśli. Według obecnej regulacji prawnej, minimalny kapitał w spółce musi wynosić 5 tys. zł i to jest to minimum, które spółka stawia do dyspozycji wierzycieli. W miarę gromadzenia majątku i w przypadku konieczności realizacji zobowiązań, środki którymi dysponuje spółka służą i są przeznaczane na pokrycie wymaganych należności, mogą więc podlegać egzekucji.

Spółka odpowiada za zobowiązania całym swoim majątkiem i ta odpowiedzialność nie jest ograniczona, na co wskazuje nazwa spółki. Ograniczona odpowiedzialność dotyczy oczywiście wspólników i dlatego spółka z o.o. jest bardzo często wybieraną formą prowadzenia działalności architektonicznej. Omawiana forma, czyli spółka z o.o. może być spółką jednoosobową a więc architekt chcący oddzielić swój majątek osobisty od tego, co zaangażował w działalność gospodarczą minimalizuje ryzyko utraty majątku osobistego.

Będąc jedynym wspólnikiem sam decyduje o kierunku prowadzonej działalność, zarządza firmą według najlepiej pojętego własnego interesu. Nie znaczy to, że w obrocie gospodarczym nie funkcjonują wieloosobowe spółki z o.o.

Wspólnicy spółki z o.o. nie odpowiadają osobiście za zobowiązania spółki, chyba, że są członkami zarządu tej spółki. Jeśli egzekucja przeciwko spółce okaże się bezskuteczna, 
członkowie zarządu odpowiadają solidarnie za jej zobowiązania. Członek zarządu może uwolnić się od odpowiedzialności, jeśli we właściwym czasie zgłoszony zostanie wniosek o ogłoszenie upadłości lub wszczęto postępowanie układowe, chyba, że zaniechanie w tym względzie było bez winy zarządu lub wierzyciel przez to nie poniósł szkody.

Drugą spółką kapitałową jest spółka akcyjna przeznaczona do prowadzenia działalności gospodarczej w większym lub w wielkim rozmiarze.

Prowadzący działalność architektoniczną rzadko wybierają tę formę organizacyjno-prawną z tego powodu, że występuje tu bariera w postaci konieczności wniesienia kapitału w wysokości minimalnej 100 tys. zł. Spółka akcyjna, jako spółka kapitałowa za zobowiązania odpowiada całym swoim majątkiem. To spółka, a nie wspólnicy pokrywają wymagane należności i stawia do dyspozycji wierzycieli cały swój majątek, a nie tylko kapitał akcyjny. Akcjonariusz, czyli wspólnik spółki akcyjnej ryzykuje tym, co do spółki wniósł, czyli swoją częścią w kapitale akcyjnym. Podobnie jak w spółce z ograniczoną odpowiedzialnością, nie ryzykuje swoim osobistym majątkiem, co jest zaletą dla prowadzących działalność architektoniczną w omawianej formie.

Zaletą spółki akcyjnej jest jeszcze to, że nie ma tu żadnego elementu osobistej odpowiedzialności za zobowiązania, nawet w odniesieniu do członków zarządu, którzy zaniedbali zgłoszenia wniosku o ogłoszenie upadłości. W spółce z o.o. taka odpowiedzialność istnieje.

Spółka akcyjna także może być spółką jednego wspólnika. Jeśli wspólnik sam zarządza spółka, to nawet w sytuacji jej niewypłacalności zarządzający nie będzie odpowiadał osobistym majątkiem. Świadomość tego faktu po stronie prowadzących działalność architektoniczną może w przyszłości działać na korzyść wyboru spółki akcyjnej, jako formy prowadzenia działalności gospodarczej.

W przypadku szerszej działalności i chęci łączenia sił i środków architekci mogą wybierać w przyszłości w większym zakresie spółkę akcyjna, biorąc pod uwagę korzystny sposób odpowiedzialności za zobowiązania.

Prowadzący architektoniczną działalność i chcący ją prowadzić również poza granicami kraju mogą korzystać z takiej formy, jaką jest spółka europejska. W każdym kraju należącym do Unii Europejskiej działalność gospodarcza może być prowadzona po założeniu w naszym kraju takiej formy, jaką jest spółka europejska. Wkład do tej spółki to co najmniej 120 tys. euro i zarejestrowanie jej w Krajowym Rejestrze Sądowym. Ponieważ spółka europejska przyjmuje formę spółki akcyjnej, więc odpowiedzialność za zobowiązania jest taka sama jak w tej spółce.

Prowadzenie działalności w formie spółki europejskiej, to omijanie barier językowych, biurokratycznych obowiązujących w kraju, w którym trzeba byłoby rejestrować działalność. Wybór formy spółki europejskiej pozwala na wybór sposobu zarządzania tą spółka, gdyż taką możliwość stwarzają obowiązujące przepisy, co też jest korzystne dla prowadzących działalność w różnych krajach unijnych.

Podsumowując należy podkreślić, że prowadzący działalność w obszarze architektury mają wiele możliwości wyboru formy, która pozwoli optymalizować odpowiedzialność za zobowiązania i przy uwzględnieniu innych czynników wpływa na efektywność prowadzonych działań. 


\section{Literatura}

Asłanowicz M., 2014, Spótka partnerska, Lexis Wexsis, Warszawa.

Gronkiewicz-Waltz H., Wierzbowski M. (red.), 2017, Prawo gospodarcze, Wolters Kluwer, Warszawa.

Kodeks cywilny, 2018, C.H. Beck, Warszawa.

Misiak W., 2017, Działalność architektoniczna w formie Spótki Partnerskiej, Oficyna Wydawnicza WSEiZ, Warszawa.

Misiak W., 2018, Prawo gospodarcze, Oficyna Wydawnicza Wyższej Szkoły Ekologii i Zarządzania, Warszawa.

Prawo handlowe - zbiór przepisów, 2014, Wolters Kluwer, Warszawa.

Wyciślok J., 2014, Spótki osobowe i ich opodatkowanie, C.H. Beck, Warszawa.

\section{Źródła prawa}

Ustawa Kodeks cywilny (Dz.U. z 2020 r., poz. 1740) tekst jednolity.

Ustawa Kodeks spółek handlowych (Dz.U. z 2020 r., poz. 1526) tekst jednolity.

Ustaw Ordynacja podatkowa (Dz.U. z 2020 r., poz. 1325) tekst jednolity.

Ustawa Prawo przedsiębiorców (Dz.U. z 2018 r., poz. 646) z późniejszymi zmianami.

Ustawa o europejskim zgrupowaniu interesów gospodarczych i spółce europejskiej (Dz.U. z 2018 r., poz. 2036) tekst jednolity. 


\section{The liability for the obligations of people running an architectural business under the regulations in force}

\section{ABSTRACT}

Architectural business shall be subjected to the same rules as any other economic activity. The way it is organized determines the manner of the liability for the obligations undertaken during the activity.

A limited liability partnership is the best option for an architectural company. It can also be run in different forms of partnership, as well as as joint-stock companies.

The organizational form determines the principles of liability for the obligations within architectural businesses.

Key words: law, commercial companies code, limited liability partnership, limited partnership, limited liability company, European company

Wanda Misiak, dr, prof. WSEiZ, specjalizuje się w zagadnieniach prawa gospodarczego.

Wyższa Szkoła Ekologii i Zarzq̨dzania, ul. Olszewska 12, 00-792 Warszawa.

Wanda Misiak, PhD, Prof at the University of Ecology and Management in Warsaw, specializes in economic law.

University of Ecology and Management, ul. Olszewska 12, 00-792 Warszawa. 